\title{
Hızla İlgili ÖSS Matematik Testi Soru İfadelerinin Kavram Yanılgıları Açısından İncelenmesi
}

DOI: 10.26466/opus. 915505

\author{
Ali Yildiz* \\ * Prof. Dr., Atatürk Üniversitesi, Kazım Karabekir Eğitim Fakültesi, Erzurum/Türkiye \\ E-Posta: ayildiz@atauni.edu.tr \\ ORCID: $\underline{0000-0001-6241-2316}$
}

\begin{abstract}
Öz
Çalışmanın amacı, ÖSYM tarafından yapılan Ö̆grenci Seçme Stnavlarındaki (ÖSS) matematik testinde yer alan hızla ilgili soru ifadelerini kavram yanılgıları açısından incelemektir. Çalışma, bir doküman incelemesidir. Doküman incelemesi, nitel araştırmalarda veri toplamak için tek başına kullanılabilir. Çalışmada ÖSYM'nin gerçekleştirdiği Öğrenci Seçme Sinavlarında kullanılan matematik testi sorularını ve çözümlerini içeren dokümanlar, betimsel analiz yaklaşımına göre incelenmiştir. Çalışma için seçilen sekiz soru ifadesi ile çözümleri arasında genelde çelişkiler oluşturan açıklama ve işlemler bulunmaktadır. Soruların hız niceliğine göre sorulması ve sürat niceliği sorulmuş gibi işlem yapılarak çözülmesi bu iddiayı doğrulamaktadır. ÖSYM'nin Öğrenci Seçme Sinavlarında (2001-2009) kullandı̆̆ hızla ilgili soruların ifadelerinde yer alan sözcüklerin kavram yanılgılarına yol açabilecek düzeyde bilimsellikten uzak ve "kavram yanılgıları" düşünülmeden kullanıldıkları söylenebilir. Matematik öğretmen adaylarma lisans programlarında verilen fizik derslerinde; yol, yer değiştirme, sürat ve hız niceliklerinin öğretimi bu çalışmanın giriş kısmında verildiği gibi uygun soru örnekleri üzerinde gösterilerek yapılması o niceliklerle ilgili kavram yanılgılarının oluşmasını veya var olanların sürdürülmesini zorlaştırarak engelleyebilir.
\end{abstract}

Anahtar Kelimeler: $\mathrm{H} z$, ÖSS matematik sorularl, Kavram yanılgıları, Doküman incelemesi. 


\title{
An Examination on Misconceptions in the Statements Regarding Velocity in the ÖSS Mathematics Test Questions
}

\begin{abstract}
The purpose of the study is to examine the questions about speed in the mathematics test of the Student Selection Examination (ÖSS) conducted by ÖSYM in terms of misconceptions. The study is a document review. Document analysis can be used alone to collect data in qualitative research. In the study, documents containing the mathematics test questions and solutions used in the Student Selection Examinations conducted by ÖSYM were analyzed according to the descriptive analysis approach. There are generally contradictory explanations and operations between the eight-question question statements chosen for the study and their solutions. Asking the questions according to the velocity quantity and solving them by acting as if the speed was asked, confirms this claim. It can be said that the words in the expressions of the questions about the velocity used by ÖSYM in the Student Selection Exams (2001-2009) are far from being scientific at a level that may lead to misconceptions and are used without thinking of "misconceptions". Teaching the quantities of distance, displacement, velocity, and speed in physics lessons given to prospective mathematics teachers in undergraduate programs by showing them appropriate question examples as given in the introduction part of this study may prevent misconceptions about those quantities or making it difficult to maintain the existing ones.
\end{abstract}

Keywords: Velocity, OSS Math Questions, Misconceptions, Document Analysis. 


\section{Giriş}

İnsanoğlu ana dilini, en kısa zamanda ve en kalıcı şekilde öğrenir (Rancière, 2015, s.13). Bu avantaja rağmen dil konusu, zor ve karışıtır. Lev Vygotsky, çocukların dil ve deneyimleri yoluyla bulundukları sosyal çevreleriyle etkileşerek öğrendiklerini, eğer sosyal çevre ve içindeki bireyler yeterli düzeyde eğitimli ise oluşacak etkileşimin çocukların bilişsel gelişimini hızlandırabileceğini iddia etmektedir (Bağcı Kılıç, 2001). Öğrenciler genelde sosyal çevrelerinde öğrendikleri ve kendileri için anlamlı buldukları dili kullanmaktadırlar. Öğrenciler tarafından anlamlı bulunan dil; bilimsel dokümanlarda, toplantılarda ve sinıflarda kullanılan dilden farklı olabilir. O nedenle bu duruma karşı tedbir alınmalı eğer seyirci kalınırsa kavramsal değişim gerçekleşmeyebilir (Gunstone and Watts, 1985) ve hatta yeni kavram yanılgılarının oluşması söz konusu olabilir. Kısacası konuşulan dil ile bilimsel dilin farklı olması, kavram yanılgılarının oluşmasının sebeplerinden biri olarak görülmektedir.

Bazı araştırmalarda (Yıldız, 2016; Yıldız, 2017a; Yıldız, 2017b; Yıldız, 2018a; Yıldız, 2018b) ortaya konan bulgulara göre kütle ile ağırlığın, yol ile yer değiştirmenin ve sürat ile hızın öğretmen adayları tarafından eş anlamlı sözcükler gibi kullanıldıkları ifade edilmektedir. Her fizik konusuyla ilgili yaygın bilinen kavram yanılgılarının bir listesinin verildiği, açıklandığı ve tartışıldığı bir dokümanda (Güneş, vd., 2017); 1şık için hızın ve süratin aynı anlamda kullanıldığı belirtilmektedir (Yıldız, 2017c). Oysa 1şığın boşlukta sürati olarak bilinen ve sayısal değeri $3 \times 10^{8} \mathrm{~m} / \mathrm{s}$ olan " $\mathrm{c}$ " sabiti $\left(\mathrm{c}=3 \times 10^{8} \mathrm{~m} / \mathrm{s}\right)$, 1şığın boşlukta yayılma hızının büyüklüğüdür yani sayısal değeridir; ışığın hızı değildir. Hız, vektörel bir niceliktir. Vektörel nicelikler için genelde sayısal değer ve birimle birlikte yön de belirtilir (Yıldız, 2020). Uluslararası niteliğe sahip fizikle ilgili ders kitaplarının (Young, Freedman and Ford, 2009; Serway and Beichner, 2010; Halliday, Resnick and Walker, 2014; Mazur, 2015) Türkçeye çevirisinde işı̆̆ın boşlukta yayılma sürati olan sabitin $\left(\mathrm{c}=3 \times 10^{8} \mathrm{~m} / \mathrm{s}\right)$, genelde ışığın boşlukta yayılma hızı olarak tercüme edilmesi hızla ilgili kavram yanılgılarının diğer bir sebebi olarak görülebilir.

Bilim insanlarının görüşleri, öğrencilere; kendi mevcut görüşlerinden daha az anlaşılabilir, daha az mantıklı ve daha az verimli görünebilir (Osborne, Bell and Gilbert, 1983). Bu durum öğrencilerin fen bilimlerini veya 
fiziği öğrenmelerinde engelleyici temel bir sorundur. Bir kavramı açılamak için kullanılan örnekler bazen öğrencilere tamamıla farklı bir anlam iletebilir ve gerçek sonucun beklenen sonuçtan farklı olmasına neden olabilir (Anderson, 1986). O nedenle kavramları, doğru anlaşılır ve yanılg1lara sebep olmayacak örneklerle anlatmak önemli ve isabetli bir tercihtir. Günlük hayatta karşımıza çıkabilecek bir örnek üzerinden yol ile yer değiştirme ve sürat ile hız niceliklerinin farklılıkları, kolay anlaşılır bir şekilde ortaya konulabilir.

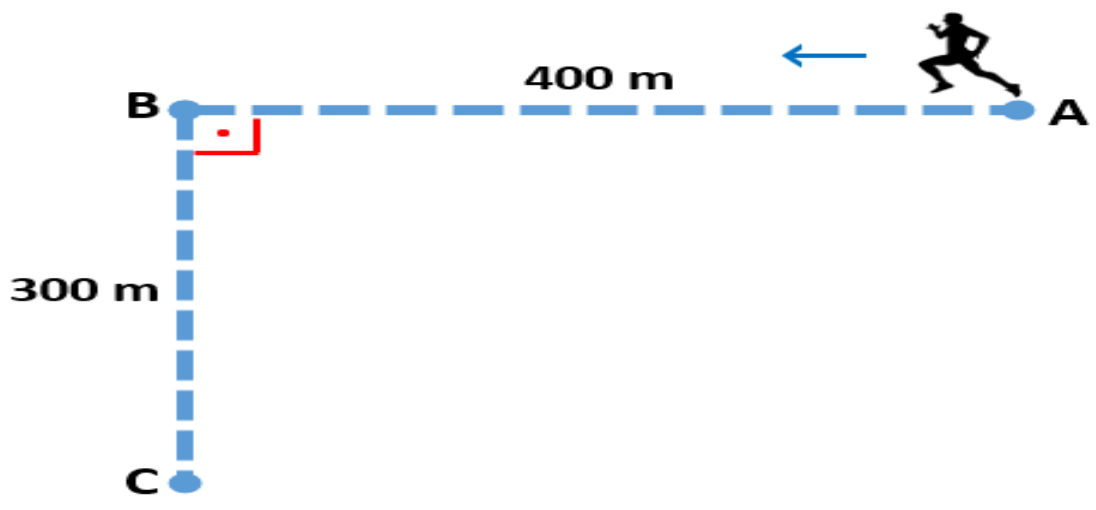

Şekil 1. Bir sporcunun antrenman yaptı̆̆ı özel bir parkur

Bir sporcunun özel bir parkurda (Şekil 1) A noktasından başlayarak aynı tempoda durmaksızın koştuğunu ve 200 saniyede $C$ noktasına vararak antrenmanını tamamladığını varsayalım. Sporcunun $C$ noktasına vardığı anda aldığ1 yolun, yaptığ1 yer değiştirmenin, ortalama süratinin ve ortalama hızının büyüklüğü nedir, hesaplayınız?

Sorunun çözümü için yapılacak açıklama ve hesaplamalar, yol ile yer değiştirme ve sürat ile hız niceliklerinin temel farklılıklarının ortaya konulmasını ve aynı zamanda kavram yanılgılarını içermeyecek şekilde doğru anlaşılmasını sağlayabilir. 


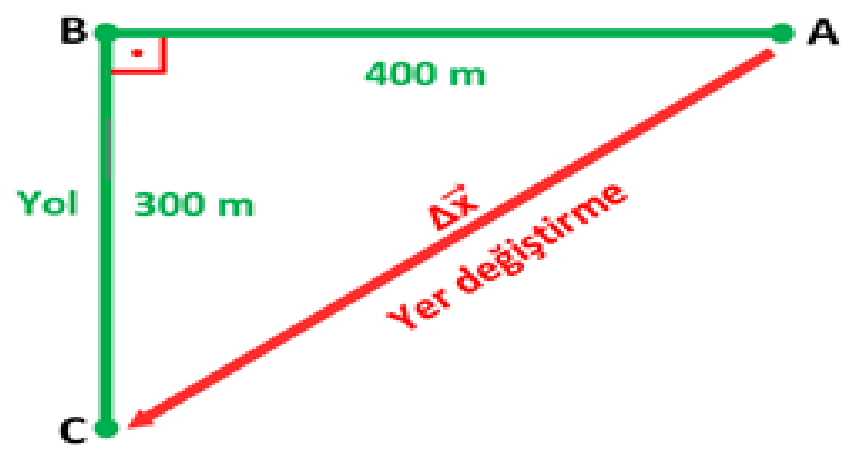

Şekil 2. Özel bir parkurda aynı tempoda durmaksızın koşan sporcunun hedefe varmasi

Sporcu, C noktasına vardığında koştuğu mesafe (yeşil renkli parkurun uzunluğu) alınan yolu verir.

Alınan Yol=400 m+300 m= 700 metre.

Yer değiştirme vektörü $(\Delta \overrightarrow{\mathrm{x}})$, hareketlinin harekete başladığı noktadan (ilk konumundan) en son bulunduğu noktaya (son konumuna) çizilen vektördür. Pisagor bağıntısı kullanılarak yapılan yer değiştirmenin büyüklüğü (kırmızı renkli vektörün uzunluğu), $(300)^{2}+(400)^{2}=(\Delta \mathrm{x})^{2}$ işlemi yapilarak $\Delta \mathrm{x}=500$ metre olarak hesaplanır.

Ortalama Sürat $=\frac{\text { Toplam yol }}{\text { Toplam zaman }}=\frac{700 \mathrm{~m}}{200 \mathrm{~s}}=3,5 \mathrm{~m} / \mathrm{s}$

Ortalama Hiz $=\frac{\text { Yer değiştirme }}{\text { Zaman }}=\frac{\Delta \mathrm{x}}{\Delta \mathrm{t}}=\frac{500 \mathrm{~m}}{200 \mathrm{~s}}=2,5 \mathrm{~m} / \mathrm{s}$

Yapılan çözüm incelendiğinde başlangıçta ortalama sürat ile ortalama hızın büyüklüğü için hesaplanan sayısal değerlerin farklı olmasının nedeni olarak yol ile yer değiştirmenin büyüklüğü için bulunan değerlerin farklı olması gibi düşünülebilir. Fakat asıl neden yol ile yer değiştirme gibi sürat ile hızın farklı nicelikler olmasıdır. Şimdi sporcunun sadece B noktasına kadar koştuğunu ve $B^{\prime}$ ye geldiğinde antrenmanını bitirdiğini varsayalım. Sporcu A noktasından B noktasına (köşesine) geldiğinde alınan yol ile yapılan yer değiştirmenin büyüklüğü eşit olduğundan (400 m) ortalama sürat ile ortalama hızın büyüklükleri de eşit hesaplanır. Ancak yol ile yer değiştirmenin büyüklüklerinin eşit olması veya hesaplanması, onları aynı nicelik yapmaz. Çünkü özünde yol skaler, yer değiştirme vektö- 
rel bir büyüklüktür. Skaler büyüklükler, bir sayısal değer (700) ve bir birimle (metre) tamamen tanımlanabilir. Fakat vektörel büyüklüklerin tamamen tanımlanabilmesi için bir sayısal değer ve bir birimle birlikte yönlerinin de belirtilmesi gerekir (Yıldız, 2017a). Sürat ile hızın büyüklükleri eşit veya farklı hesaplanabilir ama her iki durumda da bu nicelikler farklıdır. Benzer şekilde sürat skaler, hız ise vektörel bir niceliktir. Ortalama sürat hesaplanırken yol, ortalama hızın değeri hesaplanırken yer değiştirmenin büyüklügü esas alınır. Sürat ile hızın birimleri aynıdır $(\mathrm{m} / \mathrm{s})$.

\section{Çalışmanın amacı}

Çalışmanın amacı, ÖSYM tarafından yapılan Öğrenci Seçme Sınavlarında (ÖSS) matematik testinde yer alan hizla ilgili soru ifadelerini kavram yanılgıları açısından incelemektir.

\section{Yöntem}

Çalışma, bir doküman incelemesidir. Nitel araştırmaların bulguları genelde yapılan görüşme ve gözlemler ile incelenen dokümanlardan toplanan verilerle sağlanmaktadır (Merriam, 2013). Katılımcıların görüşmeler için gönüllü-istekli olmamaları veya uygun zaman bulunmaması ya da kayıt için kullanılan cihazların onlarda bazı rahatsızlıklara neden olması, dokümanların incelenmesini daha avantajlı veya zorunlu kılabilir. Bir diğer husus dokümanlara ulaşılmasının zaman ve para bakımından daha ekonomik ve kolay olması genelde doküman incelemelerinin gözlem ve görüşmelere tercih edilme sebebi olmaktadır. Alanında uzman kişiler tarafından gözden geçirilmiş, orijinalliği kontrol edilmiş, düzenlenmiş, organize edilmiş; ders kitapları, örgütsel dokümanlar, yıllık veya bilimsel çalışma raporları, lisansüstü tezler ve yayınlanmış makaleler gibi dokümanların her biri veri kaynağı olabilir. Belirtilen dokümanların nitel araştırmalarda kullanılması geçerliliğin ve güvenirliliğin artmasına katkıda bulunarak istenen desteği sağlayabilir (Yıldırım ve Şimşek, 2018).

Çalışmada ÖSYM'nin gerçekleştirdiği Öğrenci Seçme Sınavlarında kullanılan matematik testi soruları ve matematik testi sorularının çözümlerini içeren dokümanlar, betimsel analiz yaklaşımına göre incelenmiştir. 


\section{Bulgular}

ÖSYM tarafından yapılan Öğrenci Seçme Sınavlarında (ÖSS) matematik testinde yer alan hızla ilgili sorular arasından seçilerek aşağıda verilen sekiz soru (2001-2009), ÖSYM'nin basın kopyasından alınarak bu çalışma için incelenmiştir.

A ve $B$ kentleri arasındaki yolun $\frac{1}{3}$ ünde onarım yapılmaktadır. Yolun düzgün kısmında saatte $v$ km

hızla giden bir araç, onarım olan kısmında saatte $\frac{\mathrm{v}}{4} \mathrm{~km}$ hızla gitmiştir.

Bu koşullarda A ile B kentleri arasındaki yolun tamamını 12 saatte giden bu araç, onarım yapılan kısmı kaç saatte gitmiştir?
A) 3
B) 4
C) 6
D) 8
E) 9

Şekil 3. ÖSYM tarafından 2001 yılında yapılan sinavda sorulan ÖSS matematik sorusu

Sabit hızla giden A ve B hareketlilerinin yol-zaman grafiği așağıdaki gibidir.

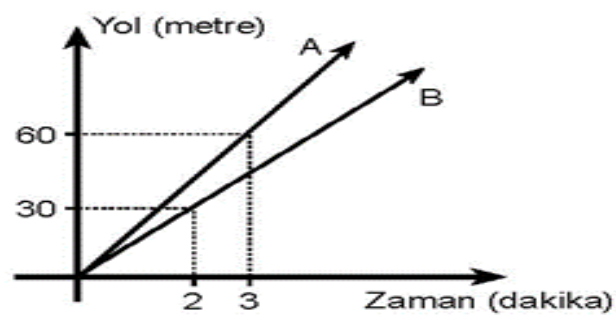

Bu iki hareketli, çevre uzunluğu 30 metre olan dairesel bir pistte aynı noktadan, aynı anda ve aynı yönde, grafikteki hızlarıyla hareket etseler hareketlerinden kaç dakika son ra ilk kez yan yana gelirler?
A) 7
B) 6
C) 5
D) 4
E) 3

Şekil 4. ÖSYM tarafindan 2001 yılında yapılan sinavda sorulan ÖSS matematik sorusu 
Uzunlukları sırasıyla $1 \mathrm{~km}$ ve 900 m olan iki tünelden, birincinin bitiş noktasıyla ikincinin başlangıç noktası arasındaki uzaklık $14 \mathrm{~km}$ dir.

Uzunluğu $100 \mathrm{~m}$, saatteki hızı $80 \mathrm{~km}$ olan bir tren, birinci tünele girdiği andan kaç dakika sonra ikinci tünelden tamamen çıkar?
A) 12
B) 15
C) 16
D) 18
E) 20

Şekil 5. ÖSYM tarafindan 2002 yılında yapılan sinavda sorulan ÖSS matematik sorusu

Hızları saatte $80 \mathrm{~km}$ ve $120 \mathrm{~km}$ olan iki araç A kentin-
den $\mathrm{B}$ kentine doğru aynı anda hareket ediyor. Hızlı
olan araç $\mathrm{B}$ ye varıp hiç durmadan geri dönüyor ve
noktasında diğer araçla karşışıyor.
Buna göre, $\frac{|\mathrm{BC}|}{\mid \mathrm{ACl}}$ oranı kaçtır?
$\begin{array}{llll}\text { A) } \frac{1}{2} & \text { B) } \frac{1}{3} & \text { C) } \frac{3}{4} & \text { C) } \frac{2}{3}\end{array}$

Şekil 6. ÖSYM tarafindan 2003 yılında yapılan sinavda sorulan ÖSS matematik sorusu

Aralarındaki yol $450 \mathrm{~km}$ olan A ve B kentlerinden ay$\mathrm{nı}$ anda, sabit hızla birbirine doğru hareket eden iki araç 2,5 saat sonra karşılaşıyor.

Bu iki araçtan birinin hızı değiştirilmediğine göre, diğerinin saatteki hızı kaç km artırıırsa karşılaş$\mathrm{ma}$, hareketten 2 saat sonra gerçekleşir?
A) 25
B) 30
C) 35
D) 40
E) 45

Şekil 7. ÖSYM tarafından 2003 yılında yapılan sınavda sorulan ÖSS matematik sorusu 
Sabit bir hızla yürüyen İrem, evden okula giderken yolun $\frac{1}{3}$ ünü yürüdüğünde matematik defterini yanına almadığını fark ediyor.

İrem yoluna devam ederse dersin başlamasından 4 dakika önce, eve dönerek defterini alıp tekrar yola çıkarsa dersin başlamasından 4 dakika sonra okula varacağına göre, ev ile okul arasını kaç dakikada almaktadır? (Dönüşlerdeki zaman kayıpları önemsenmeyecektir.)
A) 10
B) 12
C) 14
D) 15
E) 16

Şekil 8. ÖSYM tarafından 2007 yılında yapılan sınavda sorulan ÖSS matematik sorusu

Bir araç, iki kent arasındaki yolu saatte ortalama

$60 \mathrm{~km}$ hızla gidip, hiç mola vermeden saatte ortalama

$80 \mathrm{~km}$ hızla dönerek yolculuğu 7 saatte tamamlıyor.

Bu iki kent arasındaki uzaklık kaç km dir?
A) 240
B) 280
C) 300
D) 320
E) 360

Şekil 9. ÖSYM tarafından 2006 yılında yapılan sınavda sorulan ÖSS matematik sorusu

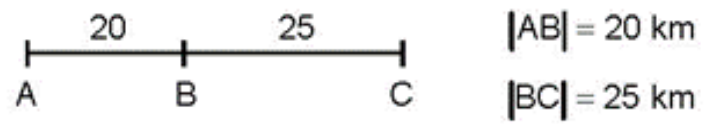

A kentinden hareket eden bir araç, saatte ortalama $60 \mathrm{~km}$ hızla giderek a dakikada $\mathrm{C}$ kentine varıyor.

Bu araç, B kentine kadar saatte ortalama $40 \mathrm{~km}$ hızla gitseydi yine toplam a dakikada $C$ kentine varmak için $B$ ile $C$ arasındaki yolu saatte ortalama kaç km hızla gitmeliydi?
A) 75
B) 80
C) 90
D) 100
E) 105

Şekil 10. ÖSYM tarafından 2009 yılında yapılan sınavda sorulan ÖSS matematik sorusu 
ÖSYM tarafından yapılan sınavlarda (ÖSS) kullanılan ve yukarıda verilen hızla ilgili sorular incelendiğinde onları hazırlayan veya kontrol ederek onay veren matematikçilerin; yol, yer değiştirme, sürat ve hız nicelikleri hakkında kavram yanılgılarına sahip oldukları söylenebilir. Soru ifadelerinde "hız", "ortalama hiz" veya "sabit hız" kavramlarının yer alması ama uzman matematikçilerin yaptığ1 çözümlerin (Gümüş, 2013) "sürat", "ortalama sürat veya "sabit sürat" kavramlarına göre yapılması iddiayı doğrulamaktadır.

Yol ile yer değiştirme ve sürat ile hız arasındaki farklılıkları bilen bir matematikçi grafikle ilgili soruyu Şekil 4' de verildiği gibi ifade etmez. Dairesel bir parkurda koşan veya dairesel bir yolda hareket eden bir nesnenin hızının sabit kalması mümkün değildir. Çünkü hareketli aynı büyüklükte (değerde) bir hızla hareket etse bile yörüngesinden dolayı hareketin yönü yani hız vektörünün yönü sürekli değişir ve yönün değişmesi nedeniyle hızı sabit kalmaz, o da değişir. Ve hatta bu hız değişimi bir merkezcil ivmenin oluşmasına neden olur. Hızın sabit kalması demek hem hızın sayısal değerinin hem de yönünün aynı kalması demektir (Yıldız, Büyükkasap ve Günel, 2011; Yıldız, 2014; Yıldız, 2017a). Ayrıca tartışılan bu soru ile çalışma için seçilen diğer sorularda sabit hızın sabit süratle karıştırıldığ1 ve onun yerine kullanıldığı anlaşılmaktadır.

Yıldız (2017a) çalışmasında Şekil 6' da verilen sorunun ifadesi ile uzman matematikçiler tarafından çözümü için yapılan açılamaların (Gümüş, 2013) çeliştiğini belirtmektedir. Çünkü dikkatli bir inceleme ile sorunun kurulumunda $80 \mathrm{~km} / \mathrm{saat}$ ve $120 \mathrm{~km} / \mathrm{saat}$ değerlerinin araçların hızları olarak verildiği ancak çözümünde araçların ortalama süratleri kabul edilerek veya alınarak işlem yapıldığı görülmektedir.

Aslında bu çalışmada incelenmek üzere seçilen soruların genelinde bazı niceliklerin doğru kullanılmadığı söylenebilir. Kavram yanılgılarına neden olabileceği düşünülen bu niceliklerin doğru kullanılması önemlidir. Genel olarak "hız" yerine "sürat", "ortalama hiz" yerine "ortalama sürat" ve "sabit hız" yerine "sabit sürat" sözcüklerinin kullanılması soru ifadelerinde uygun görülmeyerek kavram yanılgılarına yol açabileceği iddia edilen sıkıntıları veya olumsuzlukları giderebilir. Böylece soru ifadesi (soruda istenen) ile çözümü arasındaki doğru bağlantı (uyum) sağlanacağından kavram yanılgılarının oluşmasına veya var olan yanılgıların sürdürülmesine veya pekişmesine sebep olma durumu engellenebilir. 


\section{Sonuç, Tartışma ve Öneriler}

Çalışma için incelenmek üzere seçilen sekiz soru ifadesi ile çözümleri arasında genelde çelişkiler oluşturan açıklama ve işlemler bulunmaktadır. Soruların hız niceliğine göre sorulması ve sürat niceliği sorulmuş (istenmiş) gibi işlem yapılarak çözülmesi bu iddiayı doğrulamaktadır. ÖSYM'nin ÖSS sınavlarında (2001-2009) kullandığı hızla ilgili soruların ifadelerinde yer alan sözcüklerin kavram yanılgılarına yol açabilecek düzeyde bilimsellikten uzak ve "kavram yanılgıları" düşünülmeden hazırlandıkları söylenebilir. ÖSYM bünyesinde hız kavramıyla ilgili matematik soruların hazırlayan ve kontrolünü yaparak onaylayan uzmanların kavram yanılgısı endişesi taşımadıkları veya göz önünde bulundurmadıkları görülmektedir.

$\mathrm{Bu}$ çalışma için incelenen hızla ilgili matematik soru ifadeleri ve çözümleri birlikte düşünüldüğünde ulaşılan bulgular, yapılan çalışmalarda (Arons, 1990; Borghi, De Ambrosis and Massara, 1993; Yıldız, Büyükkasap and Günel, 2011; Yıldız, 2014; Y1ldız, 2016; Yıldız, 2017a; Yıldız, 2017b; Yıldız, 2018a; Yıldız, 2018b) ortaya konulan sonuçlar tarafından genelde desteklenmektedir.

Kavram yanılgılarının giderilmesi süreci, zor ve uzun zaman aldığ 1 için sabırlı olmayı gerektirir. Bu nedenle ÖSYM'nin oluşturduğu uzman gruplar tarafından matematik ve fizik başta olmak üzere diğer bütün alanlarda soru bankaları için kullanılması düşünülen soruların dil ve bilimsel içerik gibi birçok bakımdan kontrol edilerek, onaylandığ 1 bilinmektedir. Uzman grupların soru havuzlarında bulunmak üzere incelemeye aldıkları soruların, "soru ifadelerini" dil ve bilimsel içerik gibi kıstaslara ilaveten "kavram yanılg1sı" kriterini de düzeltmelere dâhil etmelerinde yarar görülmektedir. Ayrıca matematik öğretmen adaylarına lisans programlarında verilen fizik derslerinde; yol, yer değiştirme, sürat ve hız niceliklerinin öğretimi bu çalışmanın giriş kısmında ele alındığı gibi uygun soru örnekleri üzerinde gösterilerek yapılması o niceliklerle ilgili kavram yanılgılarının oluşmasını veya var olanların sürdürülmesini zorlaştırarak engelleyebilir. 


\title{
EXTENDED ABSTRACT \\ An Examination on Misconceptions in the Statements Regarding Velocity in the ÖsS Mathe- matics Test Questions \\ *
}

\author{
Ali Y1ldiz \\ Atatürk University
}

The aim of the study is to examine the questions on velocity in the mathematics test in the Student Selection Examinations conducted by ÖSYM in terms of misconceptions. The study is a document review. Documents such as textbooks, organizational documents, annual or scientific study reports, postgraduate theses, and published articles, which have been reviewed by experts in their field, whose originality has been checked, can be a source of data. The use of the specified documents in qualitative research can provide the desired support by contributing to the increase in validity and reliability (Yıldırım and Şimşek, 2018). In the study, documents containing the mathematics test questions and solutions used in the Student Selection Examinations conducted by ÖSYM were analyzed according to the descriptive analysis approach. When the questions about the velocity used in the exams (ÖSS) conducted by the ÖSYM are examined, it can be said that the mathematicians who prepared them or gave approval by checking them had misconceptions about the quantities of distance, displacement, velocity and speed. The reason is that the concepts of "velocity", "average velocity" or "constant velocity" are included in the question statements, but the solutions made by expert mathematicians (Gümüş, 2013) are made according to the concepts of "speed", "average speed or" constant speed "confirms the claim.

A mathematician who knows the difference between distance and displacement and speed and velocity does not express the question about the graph as given in Figure 4. The velocity of an object running on a circular track or moving on a circular path is not possible to remain constant because even if the moving object moves with the same speed (value), the direction of motion, i.e. the direction of the velocity vector, constantly changes due to its trajectory and its speed does not remain constant due to the change of direction. And even this change in velocity causes the 
formation of centripetal acceleration. Staying constant means that both the numerical value and the direction of the speed remain the same (Yildiz, Büyükkasap and Günel, 2011; Y1ld1z, 2014; Yıldız, 2017a). In addition, it is understood that in this question discussed and other questions selected for the study, constant velocity was confused with constant speed and used instead.

In fact, it can be said that some quantities are not used correctly in general of the questions chosen to be examined in this study. It is important to use these quantities correctly, which are thought to cause misconceptions. In general, the use of words "speed" instead of "velocity", "average speed" instead of "average velocity" and "constant speed" instead of "constant velocity" may be considered inappropriate in question expressions and may eliminate the alleged problems and negativities that may lead to misconceptions. Thus, since the correct connection (harmony) between the question statement (requested in the question) and its solution will be provided, the occurrence of misconceptions or causing existing misconceptions to be maintained or reinforced can be prevented.

It can be said that the words in the statements of the questions about the velocity used by the ÖSYM in the ÖSS exams (2001-2009) are far from being scientific at a level that may lead to misconceptions and are used without thinking of "misconceptions". It is observed that the experts who prepared and checked and approved mathematical questions related to the concept of velocity within the body of ÖSYM do not have any concern for the misconception or take it into consideration. Considering the velocity-related mathematical question expressions and their solutions together for this study, the findings obtained in the studies (Arons, 1990; Borghi, De Ambrosis and Massara, 1993; Yıldız, Büyükkasap and Günel, 2011; Y1ld1z, 2014; Y1ld1z, 2016b; Y1ld1z, 2017a) is generally supported by the results demonstrated. The process of eliminating misconceptions requires patience as it is difficult and time consuming. For this reason, it is known that the questions that are considered to be used for question banks in all other fields, especially mathematics and physics, are checked and approved in many aspects such as language and scientific content by expert groups formed by ÖSYM. It would be beneficial for expert groups to add the criterion of "question sentences" in the questions they consider in question pools in many criteria such as language and scientific content as well 
as "misconceptions" in their corrections. In addition, teaching the quantities of distance, displacement, velocity, and velocity in physics lessons given to prospective mathematics teachers in undergraduate programs by showing them the appropriate question examples as given in the introduction part of this study may prevent misconceptions about those quantities or making it difficult to maintain the previously formed ones.

\section{Kaynakça / References}

Anderson, B. (1986). The experiential gestalt of causation: A Common core to pupils' preconceptions in science. European Journal of Science Education, 8(2), 155-171.

Arons, A. B. (1990). A guide to inroductory physics teaching. New York: John Wiley. Bağcı Kılıç, G. (2001). Oluşturmacı fen öğretimi. Kuram ve Uygulamada Eğitim Bilimleri Dergisi, 1(1), 7-22.

Borghi, L., De Ambrosis, A. and Massara, C. I. (1993). Understanding average speed: A study on students aged 11 to 12 years. Physics Education, 28, 3338.

Gunstone, R. and Watts, M. (1985). Force and Motion. In R. Driver, E. Guesene \& A. Tiberghien (eds), Children's ideas in Science. Milton Keynes. Philadelphia: Open University Press.

Gümüş, O., (2013). Konularnna göre düzenlenmiş son 48 yılın matematik soruları ve çözümleri. Ankara: A Yayınları Matbaacilık Dağıtım San. Tic. Ltd. Şti.

Güneş, B., Ateş, S., Eryılmaz, A., Yürük, N., Özdemir, Ö. F., Kanll, U., Serin, G., Üstün, U., Aygün, M., Gülçiçek, Ç., Çekiç Toroslu, S. ve Daml, V. (2017). Fizikte Kavram Yamılgıları (Ed.: Bilal Güneş). Ankara: Palme Yayıncılık.

Halliday, D., Resnick, R. and Walker, J., (2014). Fiziğin Temelleri-1. Dokuzuncu Baskıdan Çeviri (Çev.: Bülent Akınoğlu ve Murat Alev). Ankara: Palme Yayıncilik.

Mazur, E., (2015). Principles \& Pratice Physics-1, 1th Edition (Çev. Ed.: Abdullah Verçin ve Ali Ulvi Yılmazer). Ankara: Nobel Akademik Yayıncılık Eğit. Danış. Tic. Ltd. Şti.

Merriam, S. B. (2013). Qualitative Research A Guide to Desing and Implementation. Tran. Ed.: S. Turan. Ankara: Nobel Akademik Yayıncılık Eğitim Danışmanlık Tic. Lmt. Şti.

Osborne, R., Bell, B. and Gilbert, J. (1983). Science teaching and children's ideas of the world. European Journal of Science Education, 5(1), 1-14. 
ÖSYM, Ölçme, Seçme ve Yerleştirme Merkezi (2021, Şubat 1). ÖSYS geçmiş yıllarda çıkmış sorular. https://www.osym.gov.tr/TR,15045/osys-cikmis-sorular.html (Erişim tarihi: 01 Şubat 2021).

Rancière, J. (2015). Cahil hoca. Çev.: Savaş Kılıç. İstanbul: Metis Yayınları.

Serway, R.A. and Beichner, R.J., (2010). Fen ve Mühendislik İ̧̧in Fizik-1, Beşinci Baskıdan Çeviri (Çev. Ed.: Kemal Çolakoğlu). Ankara: Palme Yayıncllık.

Yıldırım, A. ve Şimsek, H. (2018). Sosyal bilimlerde nitel araştırma yöntemleri, On birinci Baskı. Ankara: Seçkin Yayıncılık San. ve Tic. A. Ş.

Yıldız, A., Büyükkasap, E. ve Günel, M. (2011). Öğretmen adaylarının dairesel hareketi anlama düzeyleri. Journal of Qafqaz University: Philology and pedagogy, 32, 97-103.

Yıldız, A. (2014). Öğretmen adaylarının " $\mathrm{C}=3.10^{8} \mathrm{~m} / \mathrm{s}$ " sabitiyle ilgili görüşleri. The Journal of Academic Social Science Studies, 28 Autumn II, 28, 13-21. Doi:10.9761/JASSS2474.

Yıldiz, A. (2016). A discussion on velocity-speed and their instruction. International Physics Conference at the Anatolian Peak, IOP Publishing. Journal of Physics: Conference Series 707(2016) 012040. p.1-7. Doi: http://dx.doi.org/10.1088/1742- 6596/707/1/012040.

Yıldız, A. (2017a). Sürat ve hız niceliklerinin öss matematik sorularında kullanılan anlamlarının tartışılması. Qualitative Studies (NWSAQS), 12(3), 25-30. Doi:10.12739/NWSA.2017.12.3.E0033.

Yıldız, A. (2017b). Öğretmen adaylarının skaler ve vektörel nicelikleri anlama düzeylerinin incelenmesi. Education Sciences (NWSAES), 12(3), 86-93. Doi:10.12739/NWSA.2017.12.3.1C0670.

Yıldız, A. (2017c). Bir dokümanda kütle için belirtilen bir kavram yanılgısı hakkında yapılan bir betimlemenin tartışlması. Journal of Current Researches on Social Sciences, 7(3), 203- 208. Doi: 10.26579/jocress-7.3.13.

Yildiz, A. (2018a). Elementary education students' understanding levels of one dimensional motion and instructors' predictions related to their responses. European Journal of Education Studies, 5(3), 26-36. Doi: 10.5281/zenodo.1438463.

Yıldız, A. (2018b). Sınıf öğretmenliği öğrencilerinin vektörler konusunu anlama düzeyleri ve öğretim elemanlarının onların cevaplarına dair tahminleri. Journal of Current Researches on Social Sciences, 8(1), 273-282. Doi: 10.26579/jocress-8.1.18.

Yıldız, A. (2020). Bilimsel çalışmaların başlı̆̆ında yer alan araştırma ve inceleme sözcüklerinin doğru kullanılmasının tartışılması. The Journal of Academic Social Science, 111, 14-20. Doi:10.29228/ASOS.47160. 
Young, H. D., Freedman, R. A. and Ford, A. L. (2009). Sears and Zemansk's University Physics with Modern Physics, 12th Edition (Çev. ed.:Hilmi Ünlü). İstanbul: Pearson Education Yayıncılık Ltd. Şti.

\section{Kaynakça Bilgisi / Citation Information}

Yıldız, A. (2021). Hızla ilgili ÖSS Matematik Testi soru ifadelerinin kavram yanılgıları açısından incelenmesi. OPUS-Uluslararası Toplum Araştırmaları Dergisi, 18(42), 5715-5730. DOI: 10.26466/opus. 915505. 